Y.O. Onikienko, V.V. Pilinsky, P.V. Popovych, V.S. Lazebnyi, O.I. Smolenska, V.S. Baran

\title{
MODELLING OF OPERATION MODES AND ELECTROMAGNETIC INTERFERENCES OF GaN-TRANSISTOR CONVERTERS
}

Goal. To analyze the efficiency and EMI of a half-bridge converter built on GaN transistors at different switching frequencies and to issue recommendations for its application. Methodology. An EPC9035 development board from Efficient Power Conversion was selected for research. This board is a half-bridge converter built on the EPC2022 eGaN® transistors and contains a driver for controlling these transistors. To simplify the assessment of the conversion efficiency, it is suggested to use a computer model of the development board and LISN, which simulates the active load with the LC filter. Results. Simulation results of the converter efficiency with the nominal values of the elements according to the EPC9035 manual showed significant deviations from the calculated values at frequencies above $50 \mathrm{kHz}$. This is explained by the presence of inrush current through transistors. The inrush current depends on the «dead time» between the intervals when the transistors are open and the delays specified in the SPICE model of LM5113 driver. To reduce the amplitude of inrush current and, accordingly, to increase the duration of the "dead time" interval, it is proposed to double the capacitors responsible for the formation of this interval. Simulation of the converter efficiency with the doubled values of the circuit elements showed that the results almost coincide with the calculated values of the efficiency in the range from $0.05 \mathrm{MHz}$ to $5 \mathrm{MHz}$. The converter on the EPC2022 transistors has the highest efficiency at $50 \mathrm{kHz}$ which decreases by $0.03-0.04$ at $500 \mathrm{kHz}$. Therefore, it is recommended that the operating frequency should be set close to $500 \mathrm{kHz}$. Simulation of EMI levels resulted that the difference in the duration of the «dead time» does not have a significant effect on the levels of simulated EMI. The largest difference between the simulation results and the experiment is observed at frequencies about $30 \mathrm{MHz}$ and is 3-6 $\mathrm{dB}$. Originality. For the first time, the computer model was used to calculate the efficiency of a half-bridge converter on GaN transistors at different frequencies. Practical significance. Considering the high output current, high operating voltage and short switching times, GaN transistors are promising for use in pulse generators, power supplies with operating frequencies exceeding $500 \mathrm{kHz}$, and in powerful Class D hi-fi amplifiers with small dimensions, such as automotive ones. References 10, tables 3, figures 5.

Key words: GaN transistors, computer simulation, electromagnetics interferences, energy efficiency.

У роботі досліджено вплив частоти перетворення на ефективність роботи напівмостового перетворювача на GaN транзисторах. Наведено результати комп'ютерного моделювання такого перетворювача $з$ урахуванням втрат на різних частотах. Показано, що запропонована комп'ютерна модель дозволяе визначити рівень струму споживання, а, отже, і ККД напівмостового перетворювача на GaN транзисторах. Моделювання з параметрами, взятими зі схеми від виробника призводить до завищених оцінок споживання струму до 2,3 рази. 3міна параметрів $\boldsymbol{R} C$-кіл, ще формують інтервал «мертвого часу" транзисторів змениує похибку визначення струму спожсивння до менш як 5 \%. Збільщення тривалості «мертвого часу» суттєво не впливає на точність моделювання несиметричних електромагнітних завад і призводить до зміни їх рівня в межах 3 дБ. У результаті дослідження встановлено, щио комп'ютерна модель має достатно точність для оціночних розрахунків, а розглянуті перетворювачі на GaN транзисторах найкраще використовувати з частотами перетворення близвко 500 кГц. Такі перетворювачі можуть знайти застосування в джерелах жсивлення бортової апаратури $і$ автомобільних підсилювачах класу D. Бібл. 10, табл. 3, рис. 5.

Ключові слова: GaN-транзистори, комп'ютерне моделювання, електромагнітні завади, енергоефективність.

В работе исследовано влияние частоты переключения на эффективность работы полумостового преобразователя на GaN транзисторах. Приведены результаты компьютерного моделирования такого преобразователя с учетом потерь на разных частотах. Показано, что предложенная компьютерная модель позволяет определить уровень тока потребления, а, следовательно, и КПД полумостового преобразователя на GаN транзисторах. Моделирование с параметрами, взятыми из схемы от производителя, дает завышенное потребление тока до 2,3 раз. Изменение параметров RC-цепей, задающих интервал «мертвого времени" транзисторов уменьщает погрешность определения тока потребления до менее 5 \%. При этом, увеличение продолжительности "мертвого времени" не влияет в значительной степени на точность моделирования несимметричных электромагнитных помех, изменяя их уровень 6 пределах 3 дБ. В результате исследования установлено, что компьютерная модель имеет достаточную точность для оценочных расчетов, а рассмотрены преобразователи на GaN транзисторах лучие использовать на частотах переключения около 500 кГц. Такие преобразователи могут найти применение в источниках питания для бортовой аппаратуры и автомобильных усилителях класса D. Библ. 10, табл. 3, рис. 5.

Ключевые слова: GaN-транзисторы, компьютерное моделирование, электромагнитные помехи, энергоэффективность.

Introduction. In recent years, transistors based on gallium nitride $(\mathrm{GaN})$ and silicon carbide $(\mathrm{SiC})$ have become widespread. Such transistors have low control and switching losses, short switching time and good heat transfer. These properties give GaN transistors a number of advantages over silicon (Si) MOSFET and IGBT transistors and expand their scope. At present, GaN transistors are promising substitutes for high-power $\mathrm{Si}$ transistors. Their use ensures compliance with modern requirements for reducing energy consumption and dimensions of electronic equipment. But GaN transistors are still relatively expensive. Due to their advantages, 
$\mathrm{GaN}$ and $\mathrm{SiC}$ transistors are widely used in radars, telecommunications equipment and are promising for many applications, where the requirements for high efficiency and small size come first. For example, for use in Class D audio amplifiers and electric drives.

For example, in [1] the results of a comparative analysis of the efficiency of $\mathrm{GaN}$ and $\mathrm{SiC}$ transistors utilization for high-speed electric drives are presented. Increasing the conversion frequency, due to the use of $\mathrm{GaN}$ transistors, has reduced the losses of the rotor in the drive with permanent magnets and increased its efficiency and specific power in general. In [2] the efficiency of three transistor rectifiers is compared: IGBT, MOSFET and GaN FET. Due to the low frequency $(50 \mathrm{~Hz})$ selected, the GaN converter did not show greater efficiency than the others, but provided a lower harmonic ratio. The use of $\mathrm{SiC}$ transistors instead of IGBT in high-power converters (up to $12 \mathrm{~kW}$ ) does not provide an advantage in terms of efficiency, but allows them to be used at high operating temperatures [3].

In [4], the results of comparison of asymmetric (Common Mode) electromagnetic interferences (EMI) generated by $\mathrm{Si}$ and GaN transistors are presented. For the study, the authors chose both types of transistors, the characteristics of which are similar and little different. As a result, their study did not reveal a significant difference in interference levels in the standard frequency range from $150 \mathrm{kHz}$ to $30 \mathrm{MHz}$. Differences occurred only at frequencies above $30 \mathrm{MHz}$.

The influence of the value of the decoupling capacitor on the level of EMI generated by a half-bridge converter on GaN transistors is studied in [5]. The effect of additional capacitance on both symmetric and asymmetric interference components using a computer model is estimated. Simulation is widely used for EMI analysis because it greatly simplifies the process of research and development of converters, provides ease of model construction and the ability to quickly change it. In addition, it saves money on the development process.

However, in the literature, insufficient attention has been paid to the justification for the choice of the conversion frequency of converters on GaN transistors. Therefore, it is advisable to create a computer model of the converter, to investigate which parameters can provide the highest efficiency and how the simulation results coincide with the experimental data.

The goal of the work is to analyze the efficiency and electromagnetic interference of a half-bridge converter on $\mathrm{GaN}$ transistors at different switching frequencies using its computer model and to form recommendations for its use.

To achieve this goal it was necessary to solve the following tasks:

- evaluate the efficiency of the converter on GaN transistors depending on the frequency of conversion;

- evaluate the adequacy of the computer model of the converter to calculate the efficiency when operating at different frequencies;
- evaluate the adequacy of the computer model for calculating the EMI of the converter, measured at the output of the network equivalent;

- based on the results of research to formulate recommendations to developers on the feasibility of using $\mathrm{GaN}$ transistors for various tasks.

Description of the computer model. The EPC9035 development board from Efficient Power Conversion was chosen for the research. This board is a half-bridge converter module implemented on EPC2022 eGaN® transistors and contains a driver for controlling these transistors. Table 1 shows the main parameters of the EPC9035 board.

Table 1

The main electrical and time characteristics of the development board EPC9035

\begin{tabular}{|l|c|}
\hline \multicolumn{1}{|c|}{ Parameter } & Value \\
\hline Output voltage, V & 80 \\
\hline Output current, A & 25 \\
\hline Time of rise and fall of output voltage, $\mathrm{ns}$ & $3-5$ \\
\hline Resistance of transistors in the open state, $\mathrm{m} \Omega$ & 4 \\
\hline Minimum width of the input pulse in the «high» state, ns & 50 \\
\hline Minimum width of the input pulse in the «low» state, ns & 100 \\
\hline
\end{tabular}

The on and off times of the transistor EPC2022 are indicated approximately, they were measured during the experiment.

Computer simulation of a half-bridge converter on $\mathrm{GaN}$ transistors has previously been performed using the EPC9062 board [6]. The paper also presents the results of EMI simulation when operating on active load. The model proposed below takes into account the differences in the design of the boards, the components used and simulates the operation on active load with an LC-filter. The computer model of the EPC9035 board, connected to the power supply via the network equivalent, is shown in Fig. 1. Logic elements $U 1$ and $U 2$ are used on the EPC 9035 board as buffers and to invert the input signal. $\mathrm{RC}$ circuit consisting of $\mathrm{R} 2, \mathrm{C} 2$ and diode $\mathrm{D} 1$ forms a switching on delay of transistor Q1, RC circuit R7, C4 and diode $\mathrm{D} 2$ forms a switching on delay of transistor Q2. Chip U3 is the driver of transistors Q1 and Q2.

Components for modelling the process of EMI propagation and losses on the printed circuit board (throttles L1, L3, resistors R1, R10), four decoupling capacitors $\mathrm{C} 8-\mathrm{C} 11$ are presented in the diagram with parasitic parameters: throttles L8-L11 (inductance of terminals) and resistors R15-R18 (internal resistance). The parasitic parameters of the supply wires are presented by throttles L6, L13 and resistors R11, R20. The load of the converter is the throttle L2, the load resistor R9 and the filter capacitor $\mathrm{C} 3$ with the inductance of the terminals L4. The network equivalent is presented by capacitors C6, C7, C12, C13, throttles L5, L12 and resistors R12, R19. The input resistance of the selective microvoltmeter is presented by resistor R14. Resistor R13 takes into account the internal resistance of the power supply and the resistance of the power wires. Capacitor C5 takes into account the parasitic capacitance between the output of the converter and the «ground». 


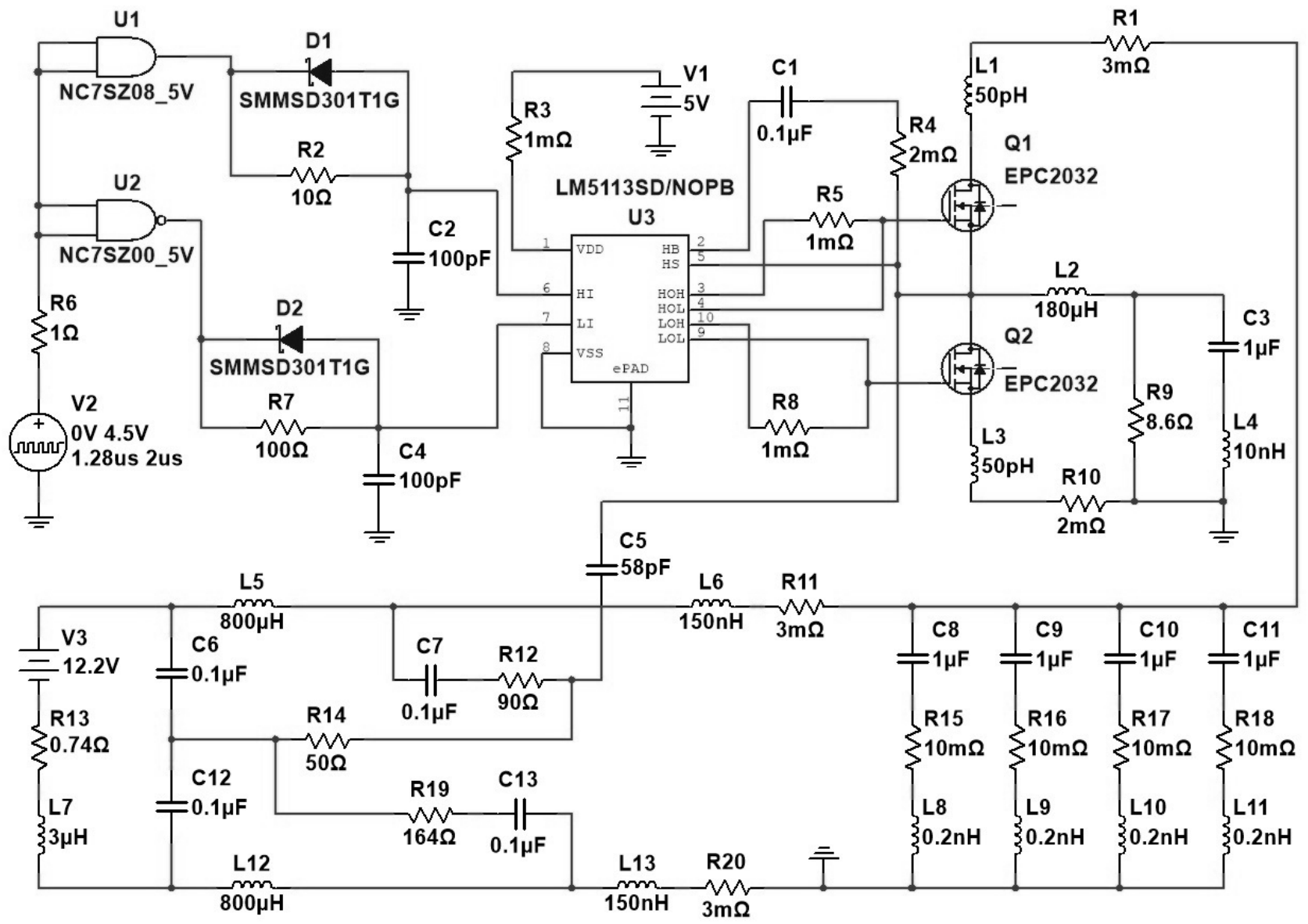

Fig. 1. Computer model of a half-bridge converter with network equivalent and power supply

Evaluation of energy efficiency of a half-bridge converter on GaN transistors. Figure 2 shows the oscillograms of the output voltage of $\mathrm{GaN}$ transistors EPC2022 during switching on (Fig. 2,a) and during switching off (Fig. 2,b).

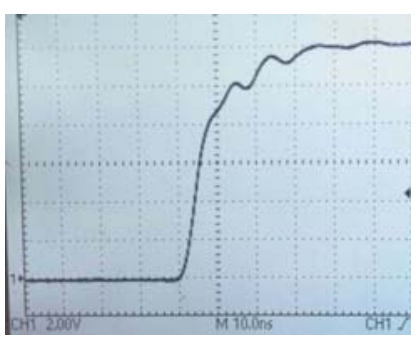

$a$

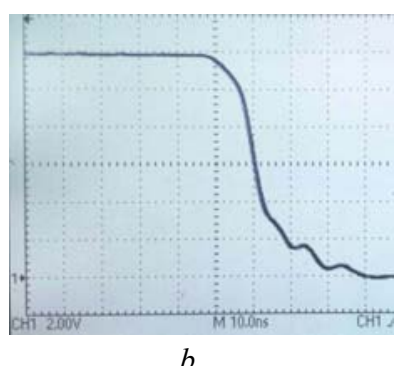

$b$
Fig. 2. Shapes of output voltage pulse fronts of the half-bridge converter EPC9035: $a$-pulse front, $\mathrm{b}$ - pulse fall

The power losses of the half-bridge converter are determined for each of the GaN transistors separately [7]. The total losses $P_{\mathrm{Q} 1}$ of the transistor Q1 consist of losses in the open state $P_{\text {cond Q1 }}$, losses on recharging the output capacitance $P_{\mathrm{OSS}}$, losses during switching on $P_{\text {on overlap, }}$ losses during switching off $P_{\text {off overlap, losses on recharging }}$ the input capacitance $P_{\mathrm{G}_{-} \mathrm{Q} 1}$. The total losses $P_{\mathrm{Q} 2}$ of the transistor Q2 consist of losses in the open state $P_{\text {cond Q2, }}$ losses on recharging the output capacitance in reverse mode $P_{\text {Oss sd }}$, losses on the built-in diode until the transistor opens $P_{\mathrm{sd}}$ and losses on recharging the input capacitance $P_{\mathrm{G}_{-} \mathrm{Q} 2}$. The losses of transistors Q1 and Q2 can be calculated by the formulas [8]:

$$
\begin{gathered}
P_{Q 1}=P_{\text {cond_Q1 }}+P_{\mathrm{OSS}}+P_{\text {on_overlap }}+P_{\text {off_overlap }}+P_{\mathrm{G} \_\mathrm{Q} 1} ; \\
P_{\mathrm{Q} 2}=P_{\text {cond_Q2 }}+P_{\mathrm{OSS} \_s d}+P_{\mathrm{sd}}+P_{\mathrm{G} \_\mathrm{Q} 2} .
\end{gathered}
$$

For transistor Q1, the losses during switching off $P_{\text {off_overlap }}$ and the losses on recharging the input capacitor recharge are insignificant and can be neglected. For transistor Q2, we can neglect the losses on recharging the output capacitor in the reverse mode $P_{\mathrm{OSS} \text { sd }}$ and the losses on recharging the input capacitor $P_{\mathrm{G}}$ Q2 . Other types of losses can be determined by the formulas:

$$
\begin{aligned}
& P_{\text {cond_Q1 }}=\left(I_{\mathrm{OUT}}^{2}+\frac{I_{\text {ripple }}^{2}}{12}\right) \cdot\left(D-t_{\mathrm{dt} 1} \cdot f_{\mathrm{sw}}\right) \cdot R_{\mathrm{DS}(\text { on }) \_\mathrm{Q} 1} \text {; } \\
& P_{\mathrm{OSS}}=f_{\mathrm{sw}} \cdot V_{\mathrm{BUS}} \cdot \int_{0}^{V_{\mathrm{BUS}}} C_{\mathrm{OSS}}\left(V_{\mathrm{ds}}\right) \cdot d V_{\mathrm{ds}} \\
& P_{\text {on_overlap }}=f_{\mathrm{SW}} \cdot \frac{1}{2} \cdot V_{\mathrm{BUS}} \cdot I_{\mathrm{L}, \text { turn_on }} \cdot\left(t_{\mathrm{cr}}+t_{\mathrm{vf}}\right) \text {; } \\
& P_{\text {cond_Q2 }}=\left(I_{\mathrm{OUT}}^{2}+\frac{I_{\text {ripple }}^{2}}{12}\right) \cdot\left(1-D-t_{\mathrm{dt} 2} \cdot f_{\mathrm{sw}}\right) \cdot R_{\mathrm{DS}(\text { on }) \_\mathrm{Q} 2} \text {; } \\
& P_{\mathrm{OSS} \_\mathrm{sd}}=\left\lfloor\left(I_{\mathrm{L}, \mathrm{turn} \_ \text {off }} \cdot V_{\mathrm{SD} 1} \cdot t_{\mathrm{SD} 1}\right)+\left(I_{\mathrm{L}, \text { turn_on }} \cdot V_{\mathrm{SD} 2} \cdot t_{\mathrm{SD} 2}\right)\right] \cdot f_{\mathrm{Sw}} \text {; } \\
& I_{\text {ripple }}=\frac{\left(V_{\mathrm{BUS}}-V_{\mathrm{OUT}}\right) \cdot D}{f_{\mathrm{SW}} \cdot L_{\mathrm{OUT}}}
\end{aligned}
$$




$$
\begin{aligned}
& I_{\mathrm{L}, \text { turn_on }}=I_{\mathrm{OUT}}-\frac{I_{\text {ripple }}}{2} ; \\
& I_{\mathrm{L}, \text { turn_off }}=I_{\mathrm{OUT}}+\frac{I_{\text {ripple }}}{2},
\end{aligned}
$$

where $V_{\mathrm{BUS}}$ is the input voltage, $I_{\mathrm{OUT}}$ is the output current, $V_{\text {OUT }}$ is the output voltage, $f_{\text {sw }}$ is the switching frequency, $L_{\text {OUT }}$ is the throttle inductance, $D$ is the fill factor, $R_{\mathrm{DS}(\text { on) } \mathrm{Q} 1}$ is the resistance of transistor $\mathrm{Q} 1$ in the open state, $R_{\mathrm{DS}(\mathrm{on}) \mathrm{Q} 2}$ is the resistance of transistor Q2 in the open state, $C_{\mathrm{OSS}}\left(V_{\mathrm{ds}}\right)$ is the dependence of the output capacitance on the resistance of the drain-source, $t_{\mathrm{cr}}$ is the time of increase of the drain current of the transistor, $t_{\mathrm{vf}}$ is the time of voltage drop of the transistor drainsource, $t_{\mathrm{dt} 1}$ is the «dead time» before switching on the transistor Q1, $t_{\mathrm{dt} 2}$ is the «dead time» before switching on transistor $\mathrm{Q} 2, t_{\mathrm{SD} 1}$ and $t_{\mathrm{SD} 2}$ are, respectively, the current flow time through the reverse diode until the opening of transistors Q1 and Q2, $V_{\mathrm{SD} 1} \mathrm{i} V_{\mathrm{SD} 2}$ are, respectively, the drain-source voltages of transistors Q1 and Q2 in reverse flow mode, $I_{\text {ripple }}$ is the maximum value of throttle current, $I_{\mathrm{L}, \text { turn_on, }} I_{\mathrm{L} \text {,turn_off }}$ are, respectively, the values of throttle current at the moment of switching on and switching off.

Even an approximate calculation of losses in a halfbridge converter according to the above formulas is quite a time-consuming procedure. To simplify the evaluation of the conversion efficiency, we can use the computer model shown in Fig. 1. To calculate it is enough to set the conversion frequency, supply voltage, output voltage and load resistance. If we know period, it is easy to determine the duration of the control pulses, after determining the fill factor by the formula

$$
D=\frac{V_{\mathrm{OUT}}}{V_{\mathrm{BUS}}} .
$$

Table 2 shows the value of the efficiency of the GaN module with an LC filter and a load of $8.6 \Omega$ with output voltage of $7.5 \mathrm{~V}$, supply voltage of $12 \mathrm{~V}$ for different conversion frequencies. The efficiency of the converter is investigated at frequencies from $50 \mathrm{kHz}$ to $5 \mathrm{MHz}$ using the proposed computer model with element denominations according to the circuit given in the Development Board EPC9031/32/33/34/35 Quick Start Guide. Also for comparison Table 2 shows the efficiency values calculated using the results of measuring the voltage at the output of the power supply and the current consumption of the EPC9035 board.

Table 2

Dependence of converter efficiency on conversion frequency with denominations of elements according to the circuit

\begin{tabular}{|c|c|c|c|c|c|c|}
\hline Frequency, MHz & 0,05 & 0,5 & 1 & 2 & 3 & 5 \\
\hline$U_{\mathrm{p}}, \mathrm{V}$ & 11,74 & 11,73 & 11,71 & 11,67 & 11,62 & 11,52 \\
\hline$I_{\mathrm{c} \text { m }}, \mathrm{A}$ & 0,59 & 0,6 & 0,63 & 0,68 & 0,75 & 0,9 \\
\hline$\eta_{\text {calc }}$ & 0,94 & 0,93 & 0,89 & 0,82 & 0,75 & 0,63 \\
\hline$U_{\mathrm{p} \text { mod }}, \mathrm{V}$ & 11,77 & 11,64 & 11,44 & 11,0 & 10,8 & 10,48 \\
\hline$I_{\mathrm{R} 13}, \mathrm{~A}$ & 0,58 & 0,75 & 1,0 & 1,6 & 1,9 & 2,33 \\
\hline$\eta_{\text {model }}$ & 0,96 & 0,75 & 0,57 & 0,37 & 0,32 & 0,27 \\
\hline
\end{tabular}

In Table 2 the following abbreviations are used: $U_{\mathrm{p}}$ is the power supply voltage, $I_{\mathrm{c} m}$ is the measured DC power consumption from the power supply, $\eta_{\text {calc }}$ is the efficiency calculated using $U_{\mathrm{p}}$ and $I_{\mathrm{c} \mathrm{m}}, U_{\mathrm{p} \bmod }$ and $I_{\mathrm{R} 13}$ are, respectively, the simulated power supply voltage and current through its internal resistance, $\eta_{\text {model }}$ is the efficiency obtained by simulation.

As follows from Table 2, measured and simulated converter efficiencies quite accurately match only at frequency of $50 \mathrm{kHz}$. As the frequency increases, the difference between them increases. From the simulation results it follows that the current consumption contains the through current of the transistors, which reaches $80 \mathrm{~A}$ at the time of switching. The shape and amplitude of the current of transistor Q1 and the voltage at the gates of transistors Q1 and Q2 are shown in Fig. 3.

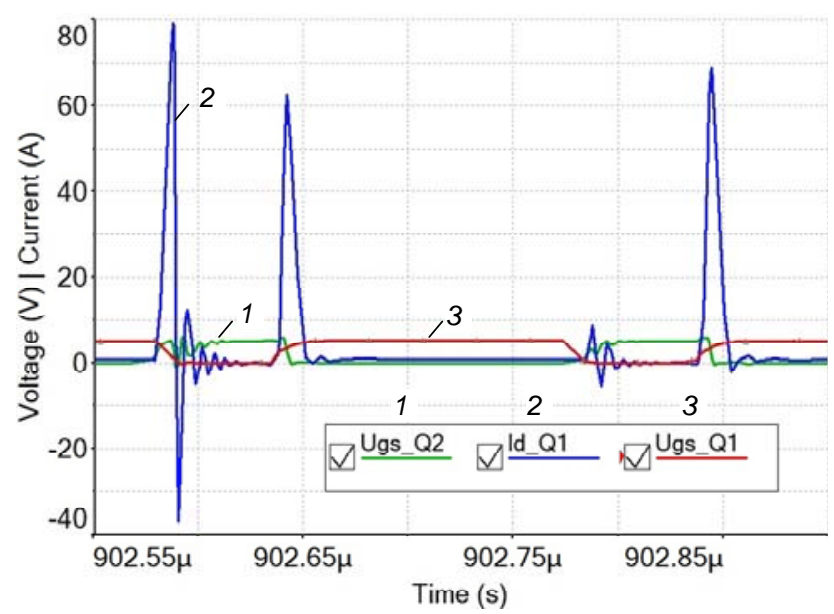

Fig. 3. Simulated control voltage and transistor drain current of the converter

As can be seen from Fig.3, jumps of through current through transistors occur when one of them has not yet closed, and the other has already opened. This current depends on the duration of the "dead time» between the intervals when transistors Q1 and Q2 are open, and the time delays that are set in the SPICE model of the LM5113 driver. The «dead time», in turn, is set by the RC link of the elements $\mathrm{R} 8, \mathrm{C} 1$ for the transistor Q1, and the RC link of the elements R7, C4 for the transistor Q2. Thus, the SPICE model of the LM5113 driver with the manufacturer-specified component denominations does not operate correctly at frequencies above $50 \mathrm{kHz}$. It is possible to reduce the amplitude of the through current through the transistors extending the duration of the «dead time» by replacing the parameters of the RC links $\mathrm{R} 8 \mathrm{C} 1$ and R7C4. Resistors are selected with a value of $100 \Omega$, and the values of capacitors are doubled to $200 \mathrm{pF}$. Table 3 shows the results of modelling with a changed duration of «dead time». Also for comparison, the value of efficiency calculated from the results of the experiment is presented.

As can be seen from Table 3, the efficiency of the half-bridge converter on $\mathrm{GaN}$ transistors, obtained in the process of modelling $\eta_{\text {model }}$ after changing the parameters of the RC links, almost coincides with the efficiency obtained experimentally $\eta_{\text {calc }}$. The converter on transistors EPC2022 has the highest efficiency at frequency 
of $50 \mathrm{kHz}$ and decreases by 0.03-0.04 at frequency of 500 $\mathrm{kHz}$. Thus, it is recommended to choose the operating frequency near this value, because with increasing frequency, the efficiency of the module decreases, and with decreasing frequency, the advantage in speed is lost.

Table 3

Dependence of converter efficiency on conversion frequency with changed denominations of model elements

\begin{tabular}{|c|c|c|c|c|c|c|}
\hline Frequency, $\mathrm{MHz}$ & 0,05 & 0,5 & 1 & 2 & 3 & 5 \\
\hline$U_{\mathrm{p} \text { mod }}, \mathrm{V}$ & 11,79 & 11,77 & 11,74 & 11,7 & 11,64 & 11,54 \\
\hline$I_{\mathrm{R} 13}, \mathrm{~A}$ & 0,56 & 0,59 & 0,61 & 0,67 & 0,76 & 0,89 \\
\hline$\eta_{\text {model }}$ & 0,98 & 0,94 & 0,91 & 0,83 & 0,74 & 0,64 \\
\hline$\eta_{\text {calc }}$ & 0,94 & 0,93 & 0,89 & 0,82 & 0,75 & 0,63 \\
\hline
\end{tabular}

Evaluation of the EMI of the converter on GaN transistors using the proposed model. An important indicator of the converter is the level of generated EMI. In [8], a study of the EMI level of a boost converter with conversion frequency of $100 \mathrm{kHz}$ is performed, in which Si IGBT IRG4BC30U, cascade GaN NCT8G206N and SiC SCT2120AF transistors in the TO-220 housing are alternately used. As a result, the difference in EMI levels in the frequency range up to $30 \mathrm{MHz}$ is not more than 3 $\mathrm{dB}$, except for one frequency with a frequency response failure, where the difference is $10 \mathrm{~dB}$. Thus, the level of EMI in a given frequency range is more influenced by the conversion frequency, the parameters of the passive elements and the design of the converter, and much less by the type of transistors.

The parameters of the printed circuit board and the design determine the level of the asymmetric component of the interferences due to the parasitic capacitance. It is formed between the power and load wires, the PCB tracks and the «ground». The parasitic capacitance between the output circuits of the converter and the «ground» has the greatest influence on asymmetric interferences.

The parasitic capacitance of the converter board is measured by the method described in [9] using an additional capacitor, which is connected between the output of the converter and «ground». The EMI level is measured with and without an additional capacitor. Then the parasitic capacitance is calculated, which is $1.8-2 \mathrm{pF}$.

Below are the results of estimating the influence of model parameters on the level of simulated EMI in comparison with the measured ones. Figure 4 shows the levels of interferences for the circuit shown in Fig. 1. Figure 4, $a$ shows the EMI with «dead time» according to the documentation, and Fig. 4,b - with extended «dead time» (capacitors C2, C4 have capacitance of $200 \mathrm{pF}$ ). The simulation is done with an additional capacitor, in order to increase the asymmetric component of the interferences. Capacitor $\mathrm{C} 5$ in the circuit has a nominal value of $58 \mathrm{pF}$ (capacitance of the EPC9035 board plus the capacitance of the additional capacitor of $56 \mathrm{pF}$ ).

As can be seen from Fig. 4, the difference in the duration of the «dead time» does not have such a significant effect on the level of simulated EMI as on the efficiency. The biggest difference between the simulation results and the experimental ones is observed at frequencies around $30 \mathrm{MHz}$.

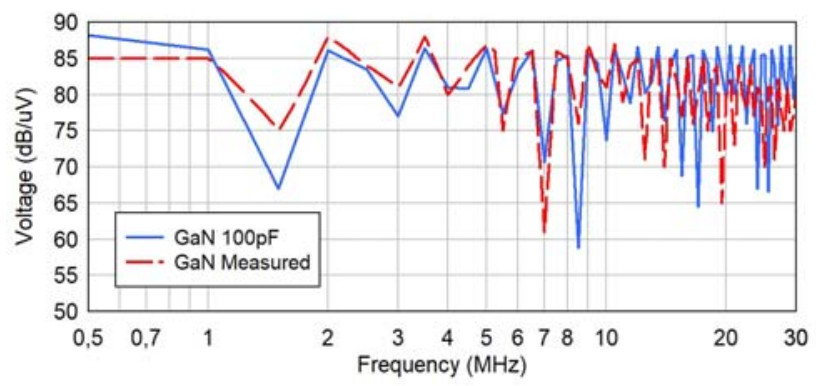

$a$

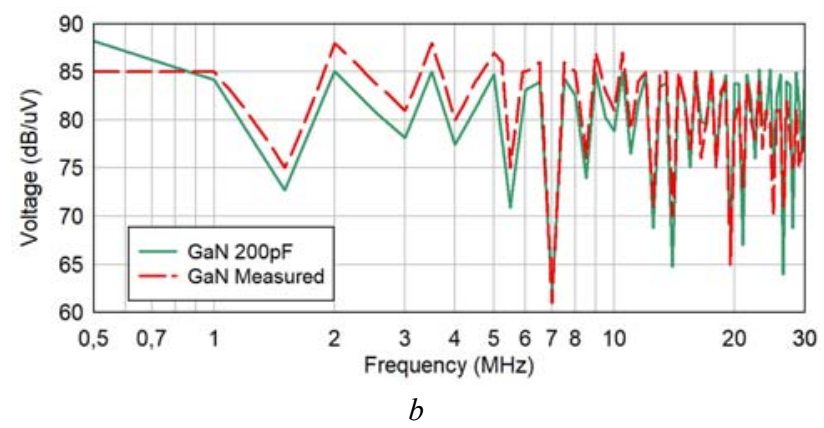

Fig. 4. EMI levels with an additional capacitance of $56 \mathrm{pF}$, connected to the output of the converters

Description of the test module and test bench. The EPC9035 is mounted on another board, which contains the elements necessary to ensure the correct order of on and off power and control signal supply in accordance with the Instructions for use of the EPC9035 board. It should be noted that the minimum duration of the output pulses provided by the LM5113 driver is 40 ns. This allowed to build on the basis of the EPC9035 board a short pulse generator with voltage of up to $90 \mathrm{~V}$ and current of up to $20 \mathrm{~A}$ [10].

As part of the test bench (Fig. 5) a selective microvoltmeter SMV11, V-shaped equivalent of the NNB101 network (Line Impedance Stabilization Network - LISN), ammeter and $12 \mathrm{~V}$ transformer power supply block with linear voltage stabilizer are used. The assembly of metal-film resistors with total resistance of 8 $\Omega$ is connected to the output of the converter by wires of minimum length.

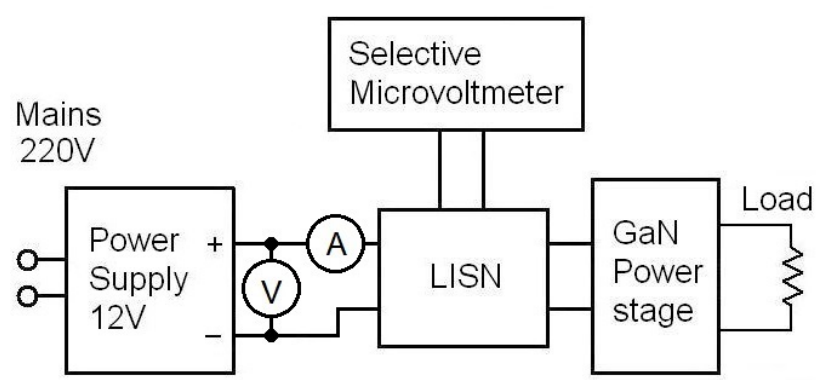

Fig. 5. Diagram of the test bench for measuring current consumption and EMI

Conclusions.

1. As a result of the investigation carried out using the proposed computer model, it is found that the simulation results with parameters taken from the manufacturer's 
circuit have a large error (up to 2.3 times) due to inaccurate SPICE model of the GaN transistor driver. Changing the parameters of the $\mathrm{RC}$ circuits which form the interval of «dead time» increases the accuracy of determining the current consumption to at least $5 \%$.

2. The efficiency of the converter on GaN transistors does not practically change up to frequency of $500 \mathrm{kHz}$, which allows the use of capacitors and throttles of small denominations and dimensions. Then, with increasing conversion frequency, the efficiency decreases.

3. For a converter with additional output capacitance, the parameters of the SPICE model of the driver do not significantly affect the accuracy of modelling of the asymmetric EMI.

4. Thus, due to high output current, high operating voltage and short switching time, GaN transistors are promising for use in pulse generators, power supply blocks with operating conversion frequencies above 500 $\mathrm{kHz}$ and in powerful Hi-Fi Class D amplifiers with low required dimensions, such as automotive ones.

5. The disadvantage of GaN transistors is the high cost, several times higher than of silicon MOSFET and IGBT transistors.

\section{REFERENCES}

1. Tüysüz A., Bosshard R. Kolar J.W. Performance comparison of a GaN GIT and a Si IGBT for high-speed drive applications. 2014 International Power Electronics Conference (IPEC-Hiroshima 2014 - ECCE ASIA), Hiroshima, 2014, pp. 1904-1911. doi: 10.1109/IPEC.2014.6869845.

2. Lee D., Soh M.Y., Teo T.H., Yeo K.S. Evaluation of Low Voltage Rectifier Design Using IGBT, MOSFET, and GaN FETs. TENCON 2018 - 2018 IEEE Region 10 Conference, Jeju, Korea (South), 2018, pp. 0389-0393. doi: 10.1109/TENCON.2018.8650321.

3. Biela J., Schweizer M., Waffler S., Kolar J.W. SiC versus $\mathrm{Si}$-Evaluation of Potentials for Performance Improvement of Inverter and $\mathrm{DC}-\mathrm{DC}$ Converter Systems by $\mathrm{SiC}$ Power Semiconductors. IEEE Transactions on Industrial Electronics, 2011, vol. 58, no. 7, pp. 2872-2882. doi: 10.1109/TIE.2010.2072896.

4. Han D., Li S., Lee W., Choi W., Sarlioglu B. Trade-off between switching loss and common mode EMI generation of GaN devices-analysis and solution. 2017 IEEE Applied Power Electronics Conference and Exposition (APEC), Tampa, FL, 2017, pp. 843-847. doi: 10.1109/apec.2017.7930794.
5. Liu X., Costa F., Revol B., Gautier C. EMI investigation in a GaN HEMT power module. PCIM Europe 2016; International Exhibition and Conference for Power Electronics, Intelligent Motion, Renewable Energy and Energy Management, Nuremberg, Germany, 2016, pp. 1-8.

6. Gedz O., Lazebnyi V., Onikienko Y., Vlasjuk A. EMI simulation of $\mathrm{GaN}$ power stage for audio class D amplifiers. 2018 14th International Conference on Advanced Trends in Radioelecrtronics, Telecommunications and Computer Engineering (TCSET), Slavske, 2018, pp. 204-207. doi: 10.1109/TCSET.2018.8336187.

7. Lidow A., Strydom J., de Rooij M., Reusch D., Glaser J. GaN Transistors for Efficient Power Conversion, Third Edition. New York, John Wiley \& Sons, 2020. doi: 10.1002/9781119594406.

8. Ibuchi T., Funaki T. A comparative study on conducted noise characteristics of $\mathrm{SiC}$ and $\mathrm{GaN}$ power transistor. 2016 International Symposium on Electromagnetic Compatibility EMC EUROPE, Wroclaw, 2016, pp. 193-198. doi: 10.1109/emceurope.2016.7739169.

9. Onikienko Y., Pilinsky V., Rodionova M. Conductive EMI of class D audio amplifiers prediction system. 2015 IEEE 35th International Conference on Electronics and Nanotechnology (ELNANO), Kiev, 2015, pp. 437-440. doi: 10.1109/elnano.2015.7146925.

10. Onikienko Y., Vlasyuk A., Marchenko O., Popovych P., Filipova N., Shevchenko I. High Frequency Half-Bridge GaNBased Pulse Generator. 2019 IEEE 39th International Conference on Electronics and Nanotechnology (ELNANO), Kyiv, Ukraine, 2019, pp. 700-703. doi: 10.1109/elnano.2019.8783532.

Received 14.02.2020

Y.O. Onikienko ${ }^{1}$, Candidate of Technical Science,

V.V. Pilinsky ${ }^{1}$, Candidate of Technical Science, Professor,

P.V. Popovych ${ }^{1}$, Candidate of Technical Science,

V.S. Lazebnyi, Candidate of Technical Science, Associate

Professor,

O.I. Smolenska ${ }^{1}$, Master of Science,

V.S. Baran ${ }^{1}$, Master of Science,

${ }^{1}$ National Technical University of Ukraine «Igor Sikorsky Kyiv Polytechnic Institute»,

37, Prospect Peremohy, Kyiv-56, 03056, Ukraine,

e-mail: yurionik@gmail.com, pww@ukr.net,.ppv_ua@ukr.net, s.smolenska.05@gmail.com, vadymbrn@gmail.com

How to cite this article:

Onikienko Y.O., Pilinsky V.V., Popovych P.V., Lazebnyi V.S., Smolenska O.I., Baran V.S. Modelling of operation modes and electromagnetic interferences of GaN-transistor converters. Electrical engineering \& electromechanics, 2020, no. 3, pp. 37-42. doi: 10.20998/2074-272X.2020.3.06. 